\title{
Adaptation of Cedro-Vermelha, Tarumã-Azeitona, Ingá-Doce, Branquilho-Bravo and Ocotea-Guaicá Seedlings to Shading Levels
}

\author{
Alexandre Techy de Almeida Garrett ${ }^{1}$ (1) 0000-0002-0954-4982 \\ Fabiana Schmidt Bandeira Peres ${ }^{1}$ (1) 0000-0002-6891-1690 \\ Mario Takao Inoue ${ }^{1}$ \\ Flávio Augusto de Oliveira Garcia ${ }^{1}$ (1) 0000-0002-5213-7979
}

\begin{abstract}
As native tree species are often used for densification, enrichment and degraded areas recovery, a better understanding of the behavior of their seedlings in response to light exposure is needed. This study evaluates the growth and morphological behavior of five native forest species of the Brazilian Mixed Ombrophilous Forest under shading levels of $90 \%, 50 \%$, and $0 \%$. The species were measured for height to root collar diameter (RCD) ratio (H:D), leaf area (LA), Dickson's quality index (DQI), and stem, leaf, and root biomass. The LA did not differ among the treatments for three species and did not differ among species in full sun. The results for H:D ratio, DQI, and biomass indicate better growth in treatments with greater light availability. The species are recommended to be used as follows: Cedro-vermelha in full sun; Tarumã-azeitona, Ingá-doce, and Ocotea-guaicá in varying environmental conditions; and Branquilho-bravo in 50\% shade and full sun conditions.
\end{abstract}

Keywords: plant biometry, seedling development, luminosity, adaptation.

\section{INTRODUCTION AND OBJECTIVES}

Understanding the growth behavior and requirements of Brazilian tree species from different types of forest is essential to effectively use these species in rural extension programs, commercial plantations, and particularly for the recovery of degraded areas and the enrichment and densification of native forests. Although some studies on the adaptation of native tree species to different environments are available, detailed information about these species is still scarce. This lack of information was highlighted in a study performed by Instituto de Pesquisas e Estudos Florestais (IPEF) (2011), in which the authors observed that of the 172 analyzed native tree species, only 49 had been studied or had silvicultural information available.

Recovery of degraded areas and recomposition in native forests often imply alterations in luminosity for seedlings, which can limit plant growth. Luminosity is a key factor for initial plant growth, as the primary source of photo assimilated energy that is converted into energy for the plant by specific receptors adapted to different light intensities, qualities, and states of polarization (Atroch et al., 2001). Furthermore, luminosity is a selective factor that can define a plant community (Silva et al., 2010). Plants have the ability to adapt to different environmental conditions that lead to growth changes, mainly in leaf area, height, internode length, and reductions in branching (Souza et al., 2008; Taiz \& Zeiger, 2006), which compensate for adverse conditions (Albuquerque et al., 2015). As a consequence, data about the relationship between native species and environmental factors, such as luminosity, can be a critical factor in choosing species for a range of purposes (Câmara \& Endres, 2008; Marimon et al., 2008; Pacheco et al., 2013; Pinto et al., 2016; Valadão et al., 2014).

One of the richest biomes in Brazil, the Atlantic Forest (Mata Atlântica), which includes the Mixed Ombrophilous Forest, also referred as Araucaria Moist Forest (WWF, 2000), is composed of economically and biologically important species, such as Araucaria angustifolia, Cedrella fissilis, and species of the genera Ocotea and Nectandra (Martins, 2012). However, of the original $200,000 \mathrm{~km}^{2}$ of the Mixed Ombrophilous Forest, only $3 \%$ remains, because of unmitigated exploitation and agricultural expansion, with only a few of these remnants

${ }^{1}$ Universidade Estadual do Centro-Oeste (Unicentro), Irati, PR, Brasil 
in a late-successional stage (MMA, 2013). Studies and data about the adaptation of native species in this forest biome are necessary, not only considering the recovery of degraded areas and forests developed for conservation and preservation purposes, but also due to advancements in the sustainable management of the Mixed Ombrophilous Forest (Lacerda et al., 2012; Pichelli, 2014).

To evaluate the growth and adaptation of plants, several variables can be assessed. In some cases, determining height and/or diameter is sufficient; however, more information is sometimes needed, including leaf size (length, width, area), total plant weight or weight of each organ, such as roots, shoots, leaves, and fruit, as well as the relationships among these parameters (Carneiro, 1995; Ferri, 1985). Another approach to infer plant growth is to observe growth balance, obtained by the use of Dickson's Quality Index (DQI), which indicates the plant quality based on its robustness and the balanced distribution of its organs (Fonseca et al., 2002).

Due to the lack of information regarding the acclimatization of seedlings of the Mixed Ombrophilous Forest and their potential silvicultural uses, this study aims to analyze the effect of different shading levels on the growth and morphology of the following native species: cedro-vermelha, Tarumãazeitona, Ingá-doce, Branquilho-bravo, and Ocotea-guaicá.

\section{MATERIALS AND METHODS}

The experiment was installed in the nursery of the Forest Engineering Department of the Universidade Estadual do Centro-Oeste (Unicentro) in Irati, Paraná, Brazil. The climate of the region is classified as $\mathrm{Cfb}$, with the occurrence of frosts in the winter, average temperature of $17^{\circ} \mathrm{C}$, and average rainfall of 1,600 mm (INMET, 2012).

Five autochthonous species of the Mixed Ombrophilous Forest were evaluated in this study: Cedrela fissilis Vell. (Meliaceae); Inga vera subsp. affinis Kunth (D.C.) T.D. Penn. (Fabaceae); Ocotea puberula (Reich.) Nees (Lauraceae); Sebastiania commersoniana (Baill.) L.B. Smith \& Downs (Euphorbiaceae); and Vitex megapotamica (Spreng) Moldenke (Lamiaceae). According to the National Cultivar Registry (MAPA, 2017), the common names of the species are: Cedro-vermelha (C. fissilis); Tarumã-azeitona (V. megapotamica); Ingá-doce (I. vera); Branquilho-bravo (S. commersoniana); and Ocoteaguaicá (O. puberula). The seedlings were produced in plastic pots with commercial substrate provided by the nursery of the Instituto Ambiental do Paraná (IAP), in the municipality of Fernandes Pinheiro. Because the age of the seedlings was unknown, they were selected according to their height, aiming to maintain a standard size. After selection, seedlings were transferred to plastic bags $(20 \mathrm{~cm} \times 8 \mathrm{~cm})$, with a substrate composed of $90 \%$ pine bark and $10 \%$ vermiculite, without the addition of fertilizers.

The bagged seedlings were then submitted to three shading treatments: $0 \%$ shading (full sun); $50 \%$ shading; and $90 \%$ shading. Shading levels were obtained with screens and radiometrically verified with a $\mathrm{LCi}$ photosynthesis reader (ADC BioScientific, Hoddesdon, UK). Initially, the shade was created in $50 \mathrm{~cm}$ high domes with a PVC structure and a gravel base. After seedling growth, the height was raised to $1.80 \mathrm{~m}$.

The experiment used a randomized block design with a factorial scheme, consisting of five species and three shading levels. Each shading treatment was composed of five blocks, and each block was composed of one plot of each evaluated species containing 11 seedlings, totaling 825 evaluated seedlings.

After two years of growth, the seedlings were measured for total height and root collar diameter (RCD). Subsequently, one seedling from each plot from all blocks was collected to assess the leaf area, and stem, leaf, and root biomass, totaling 25 seedlings selected for each species per treatment. The seedlings were selected based on the mean height of each sample, as height is associated with seedling growth and quality (Carneiro, 1995). The selected seedlings were then transferred to the laboratory and sectioned into stem, leaves, and roots. The leaf area (LA) was measured with a scanner and the software Leaf Area Measurement 1.3. The biomass of each section was assessed after drying in a stove at $50{ }^{\circ} \mathrm{C}$ until reaching a constant weight.

After measurement, height to root collar diameter ratio (H:D) and Dickson's Quality Index (DQI) were calculated based on the following parameters: seedling height (SH); stem base diameter (SBD); stem and leaf dry matter corresponding to the aerial dry matter (ADM); root dry matter (RDM); and total dry matter $(\mathrm{ADM}+\mathrm{RDM}=\mathrm{TDM})$. Following Dickson et al. (1960), the DQI was determined as (Equation 1):

$$
D Q I=\frac{T D M(g)}{\left(\frac{S H(\mathrm{~cm})}{S B D(m m)}\right)+\left(\frac{A D M(g)}{R D M(g)}\right)}
$$

Statistical analyses were performed with the software SAEG. Data normality was evaluated with the Shapiro-Wilk test at $1 \%$ significance. The data for stem, root, and leaf biomass were transformed as follows: . The interaction among factors was then analyzed through variance and, when needed, Tukey's test was applied with significance at 5\%.

\section{RESULTS AND DISCUSSION}

The LA data showed interaction among species and shading levels. Cedro-vermelha had greater LA in full sun, 
Branquilho-bravo had greater LA in 50\% shade, while the other species showed no difference in LA on different shading levels. Among species, there was statistical difference in LA only for the following shaded treatments: Branquilho-bravo had greater LA in 50\% shade, whereas Ingá-doce had greater LA in $90 \%$ shade (Table 1 ).

Table 1. Average leaf area (LA) for Cedro-vermelha, Ingá-doce, Ocotea-guaicá, Branquilho-bravo, and Tarumã-azeitona under shading levels of $90 \%, 50 \%$, and $0 \%$.

\begin{tabular}{lccc}
\multirow{2}{*}{ SPECIES } & \multicolumn{3}{c}{ Leaf area $\left(\mathrm{mm}^{2}\right)$} \\
\cline { 2 - 4 } & $\mathbf{9 0 \%}$ & $\mathbf{5 0} \%$ & $\mathbf{0} \%$ \\
\hline Cedro-vermelha & $783.91 \mathrm{Bb}$ & $10,707.49 \mathrm{Bc}$ & $49,820.20 \mathrm{Aa}$ \\
\hline Tarumã-azeitona & $3,543.25 \mathrm{Ab}$ & $10,184.53 \mathrm{Ac}$ & $58,398.19 \mathrm{Aa}$ \\
\hline Ingá-doce & $79,766.88 \mathrm{Aa}$ & $50,527.19 \mathrm{Ab}$ & $50,705.61 \mathrm{Aa}$ \\
\hline Branquilho-bravo & $37,068.95 \mathrm{Bb}$ & $111,429.20 \mathrm{Aa}$ & $50,297.27 \mathrm{Ba}$ \\
\hline Ocotea-guaicá & $27,068.33 \mathrm{Ab}$ & $34,108.80 \mathrm{Abc}$ & $22,508.18 \mathrm{Aa}$ \\
\hline
\end{tabular}

Means followed by the same capital letter in the row do not differ significantly among shading levels, and the means followed by the same lowercase letter in the column do not differ significantly among species according to the Tukey test at $5 \%$ significance.

With an increase in shade, a lower LA was observed for Cedro-vermelha, whereas Branquilho-bravo showed greater LA under $50 \%$ shading, presenting a reduction in leaf area as the shade levels increased or decreased. Shade levels have an impact on the plant leaf area in a way that a slight reduction in light exposure tends to cause an increase in leaf area, mainly in conditions of $50 \%$ shading (Pinto et al., 2016; Piña \& Arboleda, 2010; Scalon et al., 2001). On the other hand, shading over $75 \%$ negatively affects the size of leaf area, as observed for Mimosa caesalpiniifolia (Pinto et al., 2016) and Sclerolobium paniculatum (Felfili et al., 1999). Although in this study no differences in leaf area were observed among treatments for Tarumã- azeitona, Ingá-doce and Ocotea-guaicá, under greater shade levels the rate of photosynthesis, stomatal conductance and transpiration are reduced (Dalmolin et al., 2015), leading to reduced plant growth. When a reduction in LA is observed, it can suggest the inability of the plant to direct its resources to maintain leaf area (Pinto et al., 2016). In contrast, in open environments with intense radiation, simulated herein by the full sun treatment, some species can react with photoinhibition, which also leads to reductions in leaf area (Pacheco et al., 2013). In environments with intermediate levels of shading, the leaf area can increase due to changes in luminosity, humidity and temperature (Pinto et al., 2016), as observed for Branquilho-bravo with greater LA in 50\% shading.

Regarding seedling RCD and height, statistical differences were found both for shading levels and species. The RCD decreased as the shading increased, except for Ingá-doce that showed the same RCD among treatments. Comparing all species, Cedro-vermelha and Branquilho-bravo had greater RCD in full sun and $50 \%$ shade, whereas Ingá-doce had the greatest RCD in $90 \%$ shade (Table 2 ).

The height of seedlings showed less variation among treatments. Tarumã-azeitona had reduced height in $90 \%$ shade, whereas Branquilho-bravo had greater height in 50\% shade. Among species, Branquilho-bravo demonstrated the greatest height for the three treatments (Table 2).

The H:D ratio also showed statistical difference among treatments and species. The H:D ratio decreased for all species with increased light, confirming the RCD and height responses. Cedro-vermelha, Branquilho-bravo, and Ocotea-guaicá showed significant differences in H:D among shading levels. For each treatment, Branquilho-bravo and Tarumã-azeitona showed greater H:D in full sun, whereas for the other treatments a greater $\mathrm{H}: \mathrm{D}$ was observed for Branquilho-bravo (Table 3).

Table 2. Average root collar diameter $(\mathrm{mm})$ and height $(\mathrm{cm})$ for Cedro-vermelha, Ingá-doce, Ocotea-guaicá, Branquilho-bravo, and Tarumã-azeitona under shading levels of $90 \%, 50 \%$, and $0 \%$.

\begin{tabular}{|c|c|c|c|c|c|c|c|}
\hline \multirow{2}{*}{\multicolumn{2}{|c|}{$\begin{array}{l}\text { Variable } \\
\text { Shading }\end{array}$}} & \multicolumn{3}{|c|}{ Root collar diameter ( $\mathrm{mm}$ ) } & \multicolumn{3}{|c|}{ Height (cm) } \\
\hline & & $90 \%$ & $\mathbf{5 0} \%$ & $0 \%$ & $90 \%$ & $50 \%$ & $\mathbf{0} \%$ \\
\hline \multirow{5}{*}{ 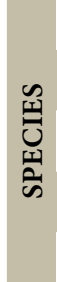 } & Cedro-vermelha & $6.49 \mathrm{Ca}$ & $10.47 \mathrm{Ba}$ & $12.97 \mathrm{Aa}$ & $28.22 \mathrm{Ab}$ & $31.96 \mathrm{Abc}$ & $27.57 \mathrm{Ac}$ \\
\hline & Tarumã-azeitona & $1.95 \mathrm{Bc}$ & $7.01 \mathrm{Ab}$ & $8.33 \mathrm{Ab}$ & $15.65 \mathrm{Bb}$ & $51.40 \mathrm{Ab}$ & $53.57 \mathrm{Ab}$ \\
\hline & Ingá-doce & $5.00 \mathrm{Aab}$ & $7.14 \mathrm{Ab}$ & $7.23 \mathrm{Ab}$ & $26.14 \mathrm{Ab}$ & $29.61 \mathrm{Ac}$ & $29.30 \mathrm{Ac}$ \\
\hline & Branquilho-bravo & $5.62 \mathrm{Bab}$ & $10.40 \mathrm{Aa}$ & $10.47 \mathrm{Aab}$ & $71.00 \mathrm{Ba}$ & $103.93 \mathrm{Aa}$ & $82.71 \mathrm{Ba}$ \\
\hline & Ocotea-guaicá & $3.45 \mathrm{Bbc}$ & $5.91 \mathrm{Ab}$ & $5.47 \mathrm{Ac}$ & $27.49 \mathrm{Ab}$ & $37.76 \mathrm{Abc}$ & $22.11 \mathrm{Ac}$ \\
\hline
\end{tabular}

Means followed by the same capital letter in the row do not differ significantly among shading levels, and the means followed by the same lowercase letter in the column do not differ significantly among species according to the Tukey's test at $5 \%$ significance. 
Table 3. Average height to diameter ratio (H:D) for Cedro-vermelha, Ingá-doce, Ocotea-guaicá, Branquilho-bravo, and Tarumã-azeitona under shading levels of $90 \%, 50 \%$ and $0 \%$.

\begin{tabular}{lccc}
\multirow{2}{*}{\multicolumn{1}{c}{ SPECIES }} & \multicolumn{3}{c}{ Height to Root Collar Diameter ratio (H:D) } \\
\cline { 2 - 4 } & $\mathbf{9 0 \%}$ & $\mathbf{5 0 \%}$ & $\mathbf{0 \%}$ \\
\hline Cedro-vermelha & $4.26 \mathrm{Ac}$ & $3.17 \mathrm{ABc}$ & $2.17 \mathrm{Bb}$ \\
Tarumã-azeitona & $3.21 \mathrm{Bc}$ & $7.27 \mathrm{Ab}$ & $6.45 \mathrm{Aa}$ \\
\hline Ingá-doce & $5.26 \mathrm{Ac}$ & $4.21 \mathrm{Ac}$ & $3.97 \mathrm{Ab}$ \\
Branquilho-bravo & $12.63 \mathrm{Aa}$ & $10.07 \mathrm{Ba}$ & $7.80 \mathrm{Ca}$ \\
\hline Ocotea-guaicá & $7.94 \mathrm{Ab}$ & $6.57 \mathrm{Ab}$ & $4.05 \mathrm{Bb}$ \\
\hline
\end{tabular}

Means followed by the same capital letter in the row do not differ significantly among shading levels, and the means followed by the same lowercase letter in the column do not differ significantly among species according to the Tukey test at $5 \%$ significance.

The greater H:D ratio observed for the seedlings cultivated in shaded conditions indicate seedling etiolation due to plant adaptation to intercept light (Paciullo et al., 2008), as observed for Cedro-vermelha, Branquilho-bravo, and Ocotea-guaicá. Since etiolated plants represent lower quality plants (Pacheco et al., 2013), the results of this study show balanced height and RCD growth in the full sun environment, representing greater plant robustness (Reyes et al., 2005). It is important to highlight that Tarumã-azeitona and Ingá-doce maintained consistent quality across all tested environments. The H:D ratio mainly showed values in the range indicated by Carneiro (1995), between 5.4 and 8.1, with lower values indicating plants with good growth balance.

Unbalanced height and RCD growth in shaded environments have been reported for several other species, such as Mimosa caesalpiniifolia and Sterculia foetida, under conditions of 50\%, $70 \%$, and $92 \%$ shade, with reduced etiolation and consequently reduced H:D ratio, when light levels are increased (Câmara \& Endres, 2008). For Bertholletia excelsa, however, greater growth was observed under $25 \%$ and $50 \%$ shading levels (Albuquerque et al., 2015). In other studies, Crescentia cujete (Piña \& Arboleda, 2010), Mimosa caesalpiniifolia (Pinto et al., 2016), Curatella americana (Dalmolin et al., 2015) and Jatropha curcas (Sesma et al., 2009) showed greater H:D ratio in shaded environments, indicating that plants in shaded conditions have greater height and RCD than plants in full sun. Evaluating the diameter is important, as it is correlated with rates of photosynthesis and transpiration (Atroch et al., 2001). Moreover, when the diameter is correlated with plant height, providing the H:D ratio, seedling quality can be assessed, once lower $\mathrm{H}: \mathrm{D}$ ratio values indicate sturdier plants in field conditions due to balanced growth (Silva et al., 2007). Thus, plants with lower $\mathrm{H}: \mathrm{D}$ ratio can be associated with a better adaptation to unfavorable conditions that may occur in degraded areas or forest remnants.

Regarding Dickson's Quality Index (DQI), statistical differences were found among species and shading treatments, with a reduced DQI as shading levels increased. For Cedrovermelha, a greater DQI was found in full sun, and the lowest DQI was observed for Branquilho-bravo in $90 \%$ shade. For each treatment, no difference was observed in the $50 \%$ and 90\% shade treatments, whereas in full sun Branquilho-bravo and Cedro-vermelha had greater DQI (Table 4).

In addition to the H:D ratio, the DQI also considers the dry biomass balance of the plant organs. Furthermore, in comparison to the H:D ratio, the DQI offers the advantage of considering the development of the root system (Carneiro, 1995). In this study, a better growth quality was observed for Tarumã-azeitona, Ingá-doce, and Ocotea-guaicá, for which the increased shading did not influence DQI. For Cedrovermelha shading reduced quality, and for Branquilho-bravo only $90 \%$ shading reduced DQI (Table 3 ).

In studies with other species native to Southern Brazil, such as Eugenia uniflora and Bauhinia forficata, height and RCD were also greater in full sun conditions than under shade (Atroch et al., 2001; Scalon et al., 2001). Meanwhile, better DQI was observed in full sun for Crescentia cujete (Piña \& Arboleda, 2010) and Curatella americana (Dalmolin et al., 2015). Other species, however, show better quality and total dry mass under low levels of shading (César et al., 2014; Pinto et al., 2016), which can explain the adaptation of Tarumã-azeitona, Ingá-doce, and Ocotea-guaicá seedlings to shaded conditions.

Table 4. Average Dickson's quality index (DQI) for Cedro-vermelha, Ingá-doce, Ocotea-guaicá, Branquilho-bravo, and Tarumã-azeitona under shading levels of $90 \%, 50 \%$, and $0 \%$.

\begin{tabular}{lccc} 
& & \multicolumn{2}{c}{ Dickson's Quality Index (DQI) } \\
\cline { 2 - 4 } \multicolumn{1}{c}{ SPECIES } & $\mathbf{9 0 \%}$ & $\mathbf{5 0 \%}$ & $\mathbf{0 \%}$ \\
\hline Cedro-vermelha & $0.90 \mathrm{Ba}$ & $1.26 \mathrm{Ba}$ & $6.95 \mathrm{Aa}$ \\
Tarumã-azeitona & $0.11 \mathrm{Aa}$ & $0.83 \mathrm{Aa}$ & $1.62 \mathrm{Ab}$ \\
Ingá-doce & $0.40 \mathrm{Aa}$ & $1.87 \mathrm{Aa}$ & $2.24 \mathrm{Ab}$ \\
Branquilho-bravo & $0.21 \mathrm{Ba}$ & $2.93 \mathrm{Aa}$ & $4.05 \mathrm{Aab}$ \\
Ocotea-guaicá & $0.23 \mathrm{Aa}$ & $0.69 \mathrm{Aa}$ & $1.52 \mathrm{Ab}$ \\
\hline
\end{tabular}

Means followed by the same capital letter in the row do not differ significantly among shading levels, and the means followed by the same lowercase letter in the column do not differ significantly among species according to the Tukey's test at $5 \%$ significance. 
In environments with low light availability, an increase in a plant's above-ground biomass in comparison to the root biomass has been observed (Felfili et al., 1999), and this can explain an unbalanced growth, as expressed in the H:D ratio and DQI for some species under shaded conditions. Thus, DQI can vary according to the phenological and physiological characteristics of each species in different environments. Mikania glomerata, an herbaceous species also present in the Mixed Ombrophilous Forest, showed greater leaf area and biomass under $80 \%$ shade, and this was interpreted as the species' phenological response (Espindola et al., 2009). Herein, a lack of shade was generally favorable for seedlings of the five studied species, and the gradual increase in shade induced unbalanced growth, as expressed by the H:D ratio. Plant adaptation to different conditions involves physiological, anatomic and ultrastructural changes, which are determined by the light intensity to which plants are submitted (Fernandes et al., 2014). Adaptation to different environments was observed on Tarumã-azeitona, Ingá-doce, and Ocotea-guaicá, due to growth capacity and biomass allocation in the different tested conditions.

In this study, seedlings had lower $\mathrm{H}: \mathrm{D}$ ratio and $\mathrm{DQI}$ in environments with greater light availability, which suggests better quality plants, as observed in other studies (César et al., 2014; Reyes et al., 2005). It is important to mention that, in studies evaluating the growth of forest species under shaded conditions, the time needed for plants to adapt to the environments must be considered, since plant growth in different environments can vary according to the growth stage (Pinto et al., 2016). Another important aspect is mortality, as the death of heliophile species under shaded conditions demonstrates intolerance of these species to excessive shade levels (Felfili et al., 1999). Although the species evaluated in this study are pioneer or initial secondary successional, and heliophiles, no significant mortality was observed associated with shading levels, which also suggests adaptation of the species to shaded conditions.

Stem and root biomass of the seedlings showed statistical difference among species and among shading levels (Figure 1). In general, stem and root biomass increased in full sun and 50\% shading, with the greatest biomass observed for Branquilho-bravo and Cedro-vermelha. Among species in each treatment, Branquilho-bravo had greater stem and root biomass in $50 \%$ shade and full sun, respectively. Differences were also observed for leaf biomass, except for Tarumãazeitona. Regarding the other species, Cedro-vermelha had greater leaf biomass under $90 \%$ shade and Branquilho-bravo under $50 \%$ shade and full sun treatments, whereas for Ingádoce and Ocotea-guaicá gains in leaf biomass were observed in full sun and 50\% shade treatments (Figure 1).
The biomass of all plant organs reduced with shading, but this was particularly notable for root biomass. This result can be associated with the characteristics of the evaluated species, as shading seems to induce biomass gains for other species (Espindola et al., 2009). Shading between 30\% and $50 \%$ can create better conditions for plant biomass production (Atroch et al., 2001; Pinto et al., 2016). In this study, greater stem and leaf biomass under shading was observed only for Branquilho-bravo.

For stem, leaf and root biomass, greater values were found for the $50 \%$ shade and full sun treatments, with a relevant difference in morphology among Branquilho-bravo, Ingá-doce, and Cedro-vermelha. Root and leaf biomass gains were also reported in full sun conditions for other species from different regions of Brazil, as well as for exotic species (Almeida et al., 2005; Atroch et al., 2001). In open environments, biomass allocation to roots is related to plant adaptations to ensure its survival within conditions of high levels of light availability and hydric changes (Marimon et al., 2008). However, other species are adapted to some levels of shade, such as Hymenaea courbaril and Enterolobium contortisiliquum seedlings, that show better root growth and total dry biomass under 50\% and $80 \%$ shading levels (Lima et al., 2010). Furthermore, RCD growth is associated with greater biomass (Pinto et al., 2016); thus, a reduction in H:D ratio, as observed in this study in full sun treatment, indicates larger diameter and hence greater seedling biomass.

For species of the Atlantic Forest, higher growth is observed in intermediary shading levels (Morais Neto et al., 2000; Valadão et al., 2014), with greater total dry biomass, and root, stem, and leaf biomass, indicating balanced partitioning of the main plant structures (Felfili et al., 1999). In contrast, other species, such Eugenia uniflora, have greater biomass in full sun (Scalon et al., 2001). Nevertheless, increased shading, particularly over $70 \%$, can be harmful to growth and cause more variations in leaf biomass (Marimon et al., 2008).

The species studied herein showed variation in their adaptation to specific environments or in more than one of the tested treatments. The growth responses to different conditions can be linked to the phytochrome, which may be associated with the habitat of each species. Moreover, light variations induce changes in ion flux, gene expression, stomatal control, and chlorophyll synthesis (Taiz \& Zeiger, 2006). Mokochinski et al. (2014) observed variations of chlorophyll content for Ingá-doce, Ocotea-guaicá, and Branquilho-bravo seedlings; Ingá-doce and Ocotea-guiacá better adapted to shade due to an increase in chlorophyll content, as the level of shade increased. On the other hand, Branquilho-bravo seedlings showed adaptation to full sun and shaded conditions. 


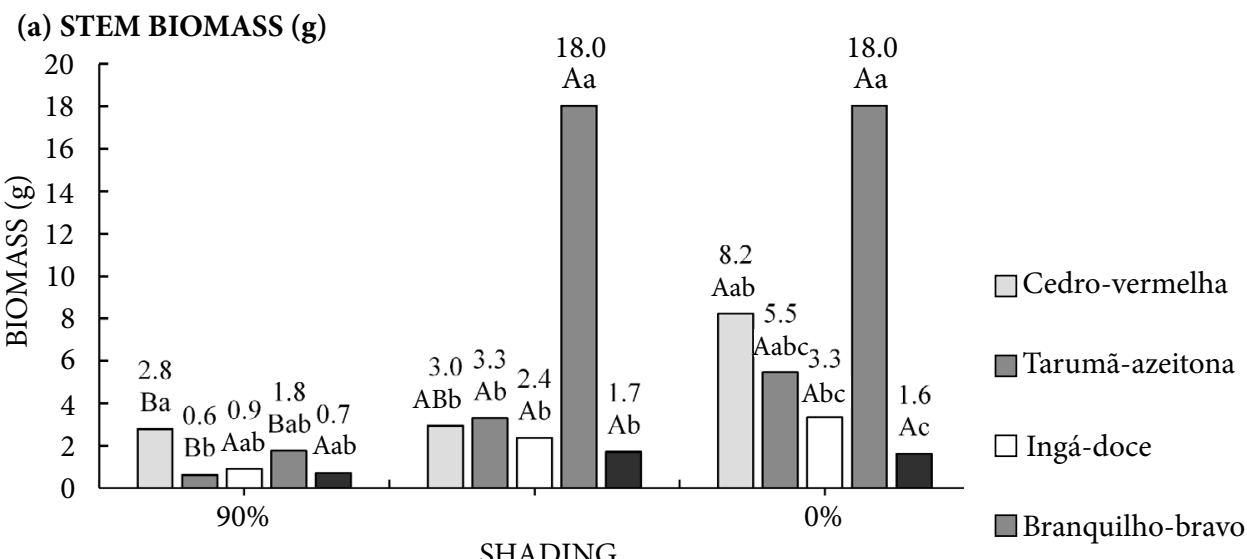

(b) ROOT BIOMASS (g)
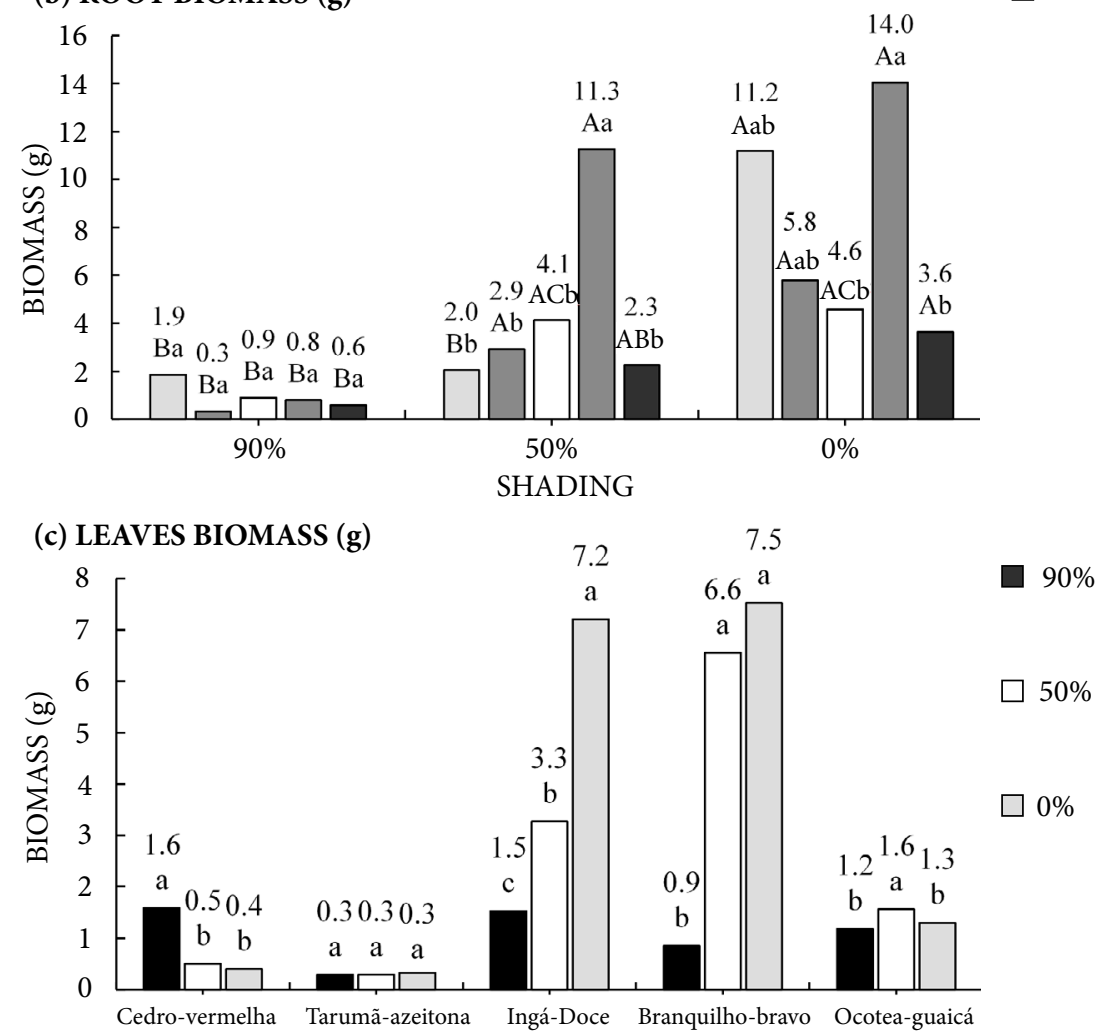

Figure 1. Stem (a), root (b) and leaf (c) biomass of Cedro-vermelha, Tarumã-azeitona, Ingá-doce, Branquilho-bravo, and Ocotea-guaicá in shade levels of $90 \%, 50 \%$, and $0 \%$. Means followed by the same capital letter do not differ significantly between shading levels, and Means followed by the same lowercase letter do not differ significantly between species according to the Tukey's test at $5 \%$ significance.

\section{CONCLUSION}

In this study, the evaluated species showed better growth and morphology in environments with greater light availability. Therefore, the species are recommended to be used as follows: Cedro-vermelha is adapted to environments with greater light intensity, as shown in the full sun treatment; Tarumã-azeitona, Ingá-doce, and Ocotea-guaicá are adapted to the different tested treatments and are suitable for use in environments with varying levels of shade; Branquilho-bravo shows adaptation to full sun and moderately shaded environments.

\section{ACKNOWLEDGEMENTS}

The authors would like to thank the Fundação Araucária for supporting the study and for the financial support. We also thank the Instituto Ambiental do Paraná for the support and donation of seedlings to conduct the experiments. Special thanks to Filemom Mokochinski and Hetyel Dolci for their help during the evaluation of the experiment. 


\section{SUBMISSION STATUS}

Received: 20 Jan. 2017

Accepted: 4 Feb. 2019

Associate editor: José Carlos Arthur Junior

(D) 0000-0002-4161-8822

\section{CORRESPONDENCE TO}

\section{Alexandre Techy de Almeida Garrett}

Universidade Estadual do Centro-Oeste (Unicentro), BR 153, km 7, Riozinho, CEP 84500-000, Irati, PR, Brasil

e-mail: garrettflorestal@gmail.com

\section{FINANCIAL SUPPORT}

Fundação Araucária.

\section{REFERENCES}

Albuquerque TCS, Evangelista, TC, Albuquerque Neto AAR. Níveis de sombreamento no crescimento de mudas de castanheira do Brasil. Revista Agro@mbiente On-line 2015; 9(4): 440-445. 10.18227/1982-8470ragro.v9i4.3025

Almeida SMZ, Soares AM, Castro EM, Vieira CV, Gajego EB. Alterações morfológicas e alocação de biomassa em plantas jovens de espécies florestais sob diferentes condições de sombreamento. Ciência Rural 2005; 35(1): 62-68.

Atroch EMAC, Soares AM, Alvarenga AA, Castro EM. Crescimento, teor de clorofilas, distribuição de biomassa e características anatômicas de plantas jovens de Bauhinia forficata Link. submetidas a diferentes condições de sombreamento. Ciência e Agrotecnologia 2001; 25(2): 853-862.

Câmara CA, Endres L. Desenvolvimento de mudas de duas espécies arbóreas: Mimosa caesalpiniifolia Benth. e Sterculia foetida L. sob diferentes níveis de sombreamento em viveiro. Revista Floresta 2008; 38(1): 43-51. 10.5380/rf.v38i1.11026

Carneiro JGA. Produção e controle de qualidade de mudas florestais. Curitiba: UFP/FUPEF; Campos: UENF; 1995.

César FRCF, Matsumoto SN, Viana AES, Bonfim JA. Crescimento inicial e qualidade de mudas de Pterogyne nitens Tull. conduzidas sob diferentes níveis de restrição luminosa artificial. Ciência Florestal 2014; 24(2): 357-366. 10.5902/1980509814573

Dalmolin ÂC, Thomas SEO, Almeida BC, Ortíz CER. Alterações morfofisiológicas de plantas jovens de Curatella americana $\mathrm{L}$. submetidas ao sombreamento. Revista brasileira de Biociências 2015; 13(1): 41-48.

Dickson A, Leaf AL, Hosner JF. Quality appraisal of white spruce and white pine seedling stock in nurseries. Forestry Chronicle 1960; 36: $10-13$. $10.5558 / \mathrm{tfc} 36010-1$

Espindola A Jr, Boeger MRT, Maccari A Jr, Reissmann CB, Rickli CB. Variação na estrutura foliar de Mikania glomerata Spreng. (Asteraceae) sob diferentes condições de luminosidade. Revista Brasileira de Botânica 2009; 32(4): 749-758. 10.1590/S010084042009000400013
Fernandes VF, Bezerra LA, Mielke MS, Silva DC, Costa LCB. Anatomia e ultraestrutura foliar de Ocimum gratissimum sob diferentes níveis de radiação luminosa. Ciência Rural 2014; 44(6): 1037-1042. 10.1590/S0103-84782014000600014

Ferri MG. Fisiologia vegetal. 2. ed. São Paulo: EPU; 1985.

Felfili JM, Hilgbert LF, Franco AC, Sousa-Silva JC, Resende AV, Nogueira MVP. Comportamento de plântulas de Sclerolobium paniculatum Vog. var. rubiginosum (Tul.) Benth. sob diferentes níveis de sombreamento, em viveiro. Revista Brasileira de Botânica 1999; 22(2): 297-301. 10.1590/S0100-84041999000500011

Fonseca EP, Valéri SV, Miglioranza E, Fonseca NAN, Couto L. Padrão de qualidade de mudas de Trema micrantha (L.) Blume, produzidas sob diferentes períodos de sombreamento. Revista Árvore 2002; 26(4): 515-523. 10.1590/S0100-67622002000400015

Instituto de Pesquisas e Estudos Florestais - IPEF. Programa cooperativo silvicultura de nativas. Piracicaba: IPEF; 2011.

Instituto Nacional de Meteorologia - INMET. Normais climatológicas do Brasil [Internet]. 2012 [cited 2020 May 15]. Available from: https://bit.ly/2Z5JfK0

Lacerda AEB, Rosot MAD, Figueredo Filho A, Garrastazú MC, Nimmo ER, Kellermann B, Radomski MI et al. Sustainable forest management in rural southern Brazil: exploring participatory forest management planning. In: Diez JJ, editor. Sustainable forest management: case studies. London: InTech; 2012. p. 97-118.

Lima ALS, Zanella F, Castro LDM. Crescimento de Hymenaea courbaril L. var. stilbocarpa (Hayne) Lee et Lang. e Enterolobium contortisiliquum (Vell.) Morong (Leguminosae) sob diferentes níveis de sombreamento. Acta Amazonica 2010; 40(1): 43-48. 10.1590/ S0044-59672010000100006

Martins SV. Ecologia de florestas tropicais do Brasil. 2. ed. Viçosa: Editora UFV; 2012.

Marimon BS, Felfili JM, Marimon BH Jr, Franco AC, Fagg CW. Desenvolvimento inicial e partição de biomassa de Brosimum rubescens Taub. (Moraceae) sob diferentes níveis de sombreamento. Acta Botanica Brasilica 2008; 22(4): 941-953. 10.1590/S010233062008000400005

Ministério do Meio Ambiente - MMA. Proteção e recuperação da floresta com araucárias. Proposta de criação de novas unidades de conservação federais no Paraná e Santa Catarina [Internet]. 2013 [cited 2016 Dec. 12]. Available from: https://bit.ly/37UWj5R

Ministério da Agricultura, Pecuária e Abastecimento - MAPA. Cultivares registradas. Registro Nacional de Cultivares [Internet]. 2017 [cited 2020 Feb. 24]. Available from: https://bit.ly/32me6lb

Mokochinski FM, Moreira VS, Vogel GF, Martinkoski L, Guilhermeti GC. Variação estacional do teor de clorofila em mudas florestais sob diferentes condições de luminosidade. Revista Verde de Agroecologia e Desenvolvimento Sustentável 2014; 9(3): 324-330.

Morais Neto SP, Gonçalves JLM, Takaki M, Cenci S, Gonçalves JC. Crescimento de mudas de algumas espécies arbóreas que ocorrem na Mata Atlântica em função do nível de luminosidade. Revista Árvore 2000; 24(1): 35-45.

Pacheco FV, Pereira CR, Silva RL, Alvarenga ICA. Crescimento inicial de Dalbergia nigra (Vell.) Allemão ex. Benth. (Fabaceae) e Chorisia speciosa A.St.-Hil (Malvaceae) sob diferentes níveis 
de sombreamento. Revista Árvore 2013; 37(5): 945-953. 10.1590/ S0100-67622013000500017

Paciullo DSC, Campos NR, Gomide CAM, Castro CRT, Tavela RC, Rossiello ROP. Crescimento de capim-braquiária influenciado pelo grau de sombreamento e pela estação do ano. Pesquisa Agropecuária Brasileira 2008; 43(7): 917-923. 10.1590/S0100-204X2008000700017

Piña M, Arboleda ME. Efecto de dos ambientes lumínicos en el crecimiento inicial y calidad de plantas de Crescentia cujete. Bioagro 2010; 22(1): 61-66.

Pichelli KR. Pesquisa pode reverter ameaça de extinção da araucária [Internet]. 2014 [cited 2016 Dec. 20]. Available from: https://bit. ly/2TcjCm7

Pinto JRS, Dombroski JLD, Santos JH Jr, Souza GO, Freitas RMO. Growth of Mimosa caesalpiniifolia Benth., under shade in the northeast semi-arid region of Brazil. Revista Caatinga 2016; 29(2): 384-392. 10.1590/1983-21252016v29n215rc

Reyes JR, Aldrete A, Cetina Alcalá VM, López Upton J. Producción de plántulas de Pinus pseudostrobus var. Apulcensis en sustratos a base asserín. Revista Chapingo. Serie Ciencias Florestales y del Ambiente 2005; 11(2): 105-110.

Silva RR, Freitas GA, Melo AV, Pietralonga AG, Aguiar RWS, Pelúzio JM, Nascimento IR. Potencial de desenvolvimento inicial da Aspidosperma polyneuron Müll em projetos de recuperação de área degradada na região sudeste da Amazônia Legal. Pesquisa Aplicada \& Agrotecnologia 2010; 3(1): 79-85.
Silva RR, Freitas GA, Siebeneichler SC, Mata JF, Chagas JR. Desenvolvimento inicial de plântulas de Theobroma grandiflorum (Willd. ex Spreng.) Schum. sob influência de sombreamento. Acta Amazonica 2007; 37(3):365-370. 10.1590/S0044-59672007000300007

Scalon SPQ, Scalon Filho H, Rigoni MR, Veraldo F. Germinação e crescimento de mudas de Pitangueira (Eugenia uniflora L.) sob condições de sombreamento. Revista Brasileira de Fruticultura 2001; 23(3): 652-655. 10.1590/S0100-29452001000300042

Sesma RB, Demuner VG, Helbling SA. Efeito de diferentes níveis de sombreamento sobre o crescimento inicial de Jatropha curcas L. em casa de vegetação. Natureza on line 2009; 7(1): 31-36.

Souza GS, Silva SA, Cosmi FC, Moraes WB, Cardoso LC. Determinação de clorofila em folhas de sombra e sol em plantas de jamelão. In: XII Encontro Latino-Americano de Iniciação Científica e VIII Encontro Latino-Americano de Pós-Graduação; 2008; São José dos Campos: Universidade do Vale do Paraíba; 2008. p. 1-4.

Taiz L, Zeiger E. Fisiologia vegetal. Trad. ER Santarém, JEA Mariath, LV Astarita, LR Dillenburg, LMG Rosa, PL Oliveira. Porto Alegre: Artmed; 2006.

Valadão MX, Marimom BH Jr, Morandi PS, Reis SM, Oliveira B, Oliveira EA, Marimom BS. Desenvolvimento inicial e partição de biomassa de Physocalymma Scaberrimum Pohl (Lythraceae) sob diferentes níveis de sombreamento. Scientia Forestalis 2014; 42(101): 129-139.

World Wildlife Fund for Nature - WWF. Araucaria moist forests. Washington; 2000. 